\title{
Relationship between boreholes productivity and major fractures extracted from satellite images of katiola region
}

\author{
Gnamba Franck Maxime ${ }^{1 *}$, Baka Derving ${ }^{2}$, Kpan Oulai Jean Gautier ${ }^{3}$, Oga \\ Yeï Marie Solange ${ }^{4}$
}

\author{
${ }^{1}$ Department of geosciences, Faculty of Biological Sciences, Peleforo Gon Coulibaly University of Korhogo, BP 1328 Korhogo, (Côte \\ d'Ivoire) \\ ${ }^{2}$ Laboratory of Technical sciences of Water and Environment, Faculty of hearth sciences and mineral resources, Félix Houphouët-Boigny \\ University of Abidjan, 22 BP 582 Abidjan 22, (Côte d'Ivoire \\ ${ }^{3}$ Department of geosciences, Faculty of biological sciences, Peleforo Gon Coulibaly University of Korhogo, BP 1328 Korhogo, (Côte \\ d'Ivoire) \\ ${ }^{4}$ Laboratory of Technical sciences of Water and Environment, Faculty of Hearth Sciences and Mineral Resources, Félix Houphouët-Boigny \\ University of Abidjan, 22 BP 582 Abidjan 22, (Côte d'Ivoire) \\ *Corresponding author
}

\begin{abstract}
The hard rock systems of crystalline basement are now much more under consideration as they may actually constitute viable groundwater resources. The area of katiola is located in the North-Center part of Côte d'Ivoire and belongs to Paleoproterozoic domain, where fractures constitute preferential of flow and accumulation groundwater. This study aims to establish the relationship between the wells efficiency and the structural lineaments detected. The map of major fractures was carried using a $50 x 50$ $\mathrm{cm}$ radar image processing. A total of 323 major fractures were carried out with a dominant direction N90-100. The flow map was surimposed to those of major fractures to show the relationship between the wells efficiency and the structural lineaments detected. Several boreholes with low flows $(0<Q<2.5$ $\left.\mathrm{m}^{3} / \mathrm{h}\right)$ are not superimposed on the major structural lineaments detected and seem have to be implanted using simple geomorphological characteristics. Whoever, more of wells with high flow $\left(Q \geq 5 \mathrm{~m}^{3} / \mathrm{h}\right)$ are match and overlap with open and interconnected fractures. There is an influence of distance between boreholes and major accidents on the productivity of the works. This result show that fractures arrangement and interconnection degree take an important role in storage and conduct properties of hard rock systems in Katiola area. This approach may be used as an indirect mean of fracture network validation which can be used during the future drilling campaigns.
\end{abstract}

Keywords - Côte d'Ivoire, fractures, Katiola, relationship, satellite images, well efficiency.

\section{INTRODUCTION}

Hydrogeological knowledge of crystalline reservoirs is essential on a global scale, both for the supply of drinking water, particularly for developing countries where a large part of the water resources are concentrated in crystalline contexts (Inde, Afrique, Asie...) (Roques, 2013). Crystalline basement aquifers consisting of plutonic rocks (granite) and metamorphic rocks (shales) are present on all continents (Figure 1). They are typically composed of fractured crystalline bedrock and a partially altered encasing material (Wyns et al., 2004). These fractured basement hydrosystems are known for their structural complexity and the associated resources reflect this complexity. The study of crystalline and crystallophellian aquifer systems in West Africa is fundamental and essential for the determination of groundwater catchment areas, their management and their protection (Bassolé et al., 2001; Biémi, 1992; Dewandel et al., 2006; Kouamé 1999, 2010; Jourda, 2005; Lasm et al., 2012 ; Maréchal et al. 2006). It is the geometric organization of the fracture network that determines solute transfers in fractured basement environment (Kouamé, 2005). In Côte d'Ivoire, most of the water resources are confined in the fractured basement reservoirs, which represent more than $97.5 \%$ of 
the country's geological context. Several studies here and elsewhere have highlighted the good correlation between the productivity of wells and the discontinuities detected by the lineaments (Fernandes and Rudolph, 2001; Jourda 2005; Kouamé et al., 2010; Koïta et al., 2010; Larsson 1972; Naik et al., 2001, Neves and Morales, 2007; Savané, 1997). Indeed, knowledge of the exact relationship between fluids and fractures is essential both for storage safety and for optimizing production in cracked reservoirs. In the Katiola area, drinking water supply is provided mainly through boreholes capturing these aquifers from cracks in the Paleproterozoic basement (Gnamba, 2014). Despite the government's efforts to meet the sustainable water needs of the ever-growing population, many challenges remain to be met, as the rate of water supply in the region is between 50 and $60 \%$. In addition, many drillings carried out during the drilling compaigns were negative (air lift flow at the end of drilling less than 1 $\mathrm{m}^{3} / \mathrm{h}$ ) or dry up. In the region, statistical studies have highlighted some parameters influencing drilling productivity, as well as rocks with the best hydrogeological potential (Gnamba et al., 2014). However, further investigations are needed to understand the complexity of these hydrosystems in a fractured basement environment. The study of the relationships between boreholes and fractures may thus be interesting to explain the hydraulic role played by the different tectonic accidents directions (Biémi, 1997). This is the context of this study which aim is to establish the link between drilling productivity and discontinuities detected as major lineaments in the Katiola area. The architecture of this article presents three parts that address respectively: i) the geographical and hydrogeological context of the study area; ii) the data used and the methods implemented; iii) the results of the study the major accidents influence on the productivity of the boreholes and their discussion

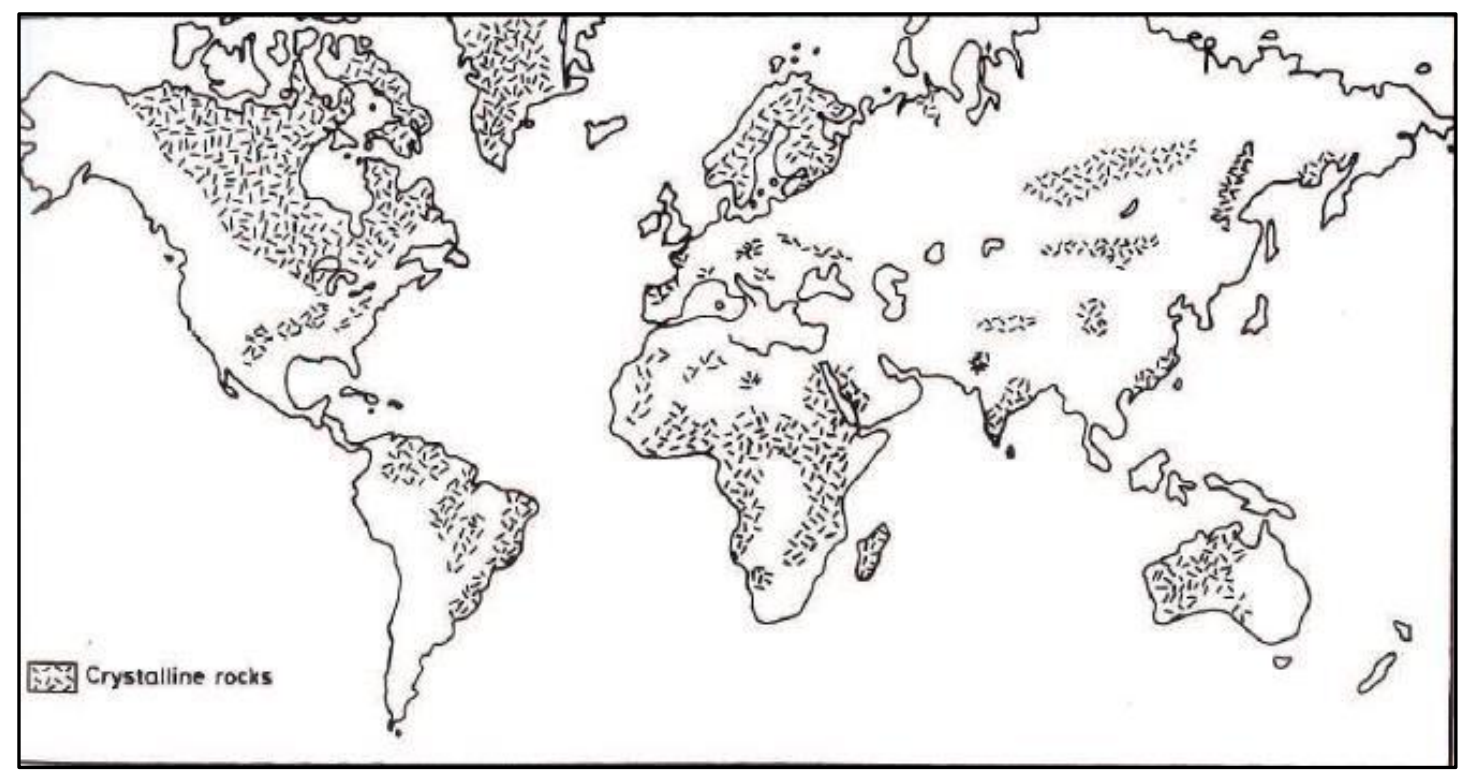

Fig. 1. Distribution map of crystalline basement aquifers (Roques, 2013)

\section{STUDY AREA}

\subsection{Geographical context}

The study area (Katiola) is located in the Centre-North of Côte d'Ivoire about $50 \mathrm{~km}$ from Bouaké. Katiola is the capital of the Hambol region and is between longitudes $4^{\circ} 75$ and $5^{\circ} 75$ West and latitudes $7^{\circ} 95$ and $9^{\circ} 45$ North (Figure 2). It covers an area of $9452 \mathrm{~km} 2$ or about $3 \%$ of the total area of the territory. The most recent census of 2014 shows an estimated population of 429977 (RGPH, 2014). The climate context of the region derives from the interface between Sudanese and Guinean climate. Annual precipitation is estimated at about $1200 \mathrm{~mm}$ per year. The average air temperature varies very little (between 23 and $27^{\circ} \mathrm{C}$ ). The daily amplitude is quite low in the rainy season $\left(7^{\circ} \mathrm{C}\right)$ but it becomes important during harmattan period when the lowest night temperatures occur (absolute minimum temperatures $15^{\circ} \mathrm{C}$ ). The vegetation cover is dominated by savannah, however on the southern margins of the region, below the latitude of the city of Katiola, there are mesophilic forest formations. Islets of dry dense forests, gallery and/or rock forests coexist with specific Sudanese formations; tree and shrub savannas, clear wooded savannahs, and grassy savannahs. The region is drained by two main rivers and their tributaries which 
constitute natural boundaries of the department, the Bandama and its tributaries (Bou, Naramou, Nabion, etc) in the West and the N'Zi and its tributaries (Loho, Kiohan, etc) in the East.

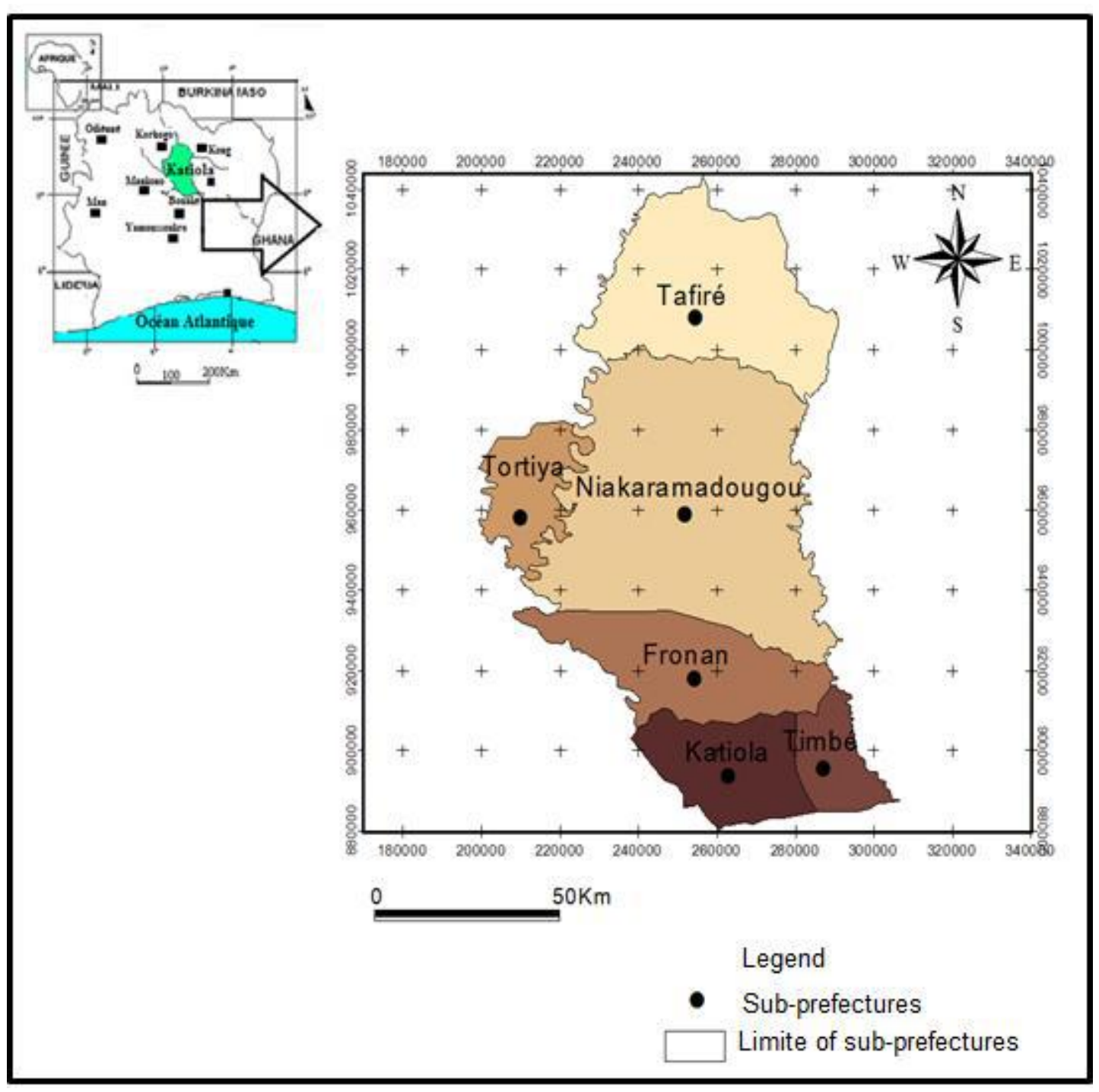

Fig. 2. Location of study area

\subsection{Geological and hydrogeological overview of the study area}

The region of Katiola belongs to the Eburnéen domain of Côte d'Ivoire. In this area, the geological formations are mainly made up of granitoids. These formations outcrop as slabs, domes and scree. They were affected by the important tectonic phenomena that helped set up the Bandama River. On these granitoids, fractures filled with quartz veins and pegmatite veins of direction $\mathrm{N} 180^{\circ}$. Intrusive microgranites in these fractures are also observed in places. In addition to these crystalline formations, metavolcanites, metasediments and green rock belts are also observed (Figure 3 and 4).

Hydrogeologically, the study area, like most of the country, belongs to the crystalline or crystallophyllian basement.
The aquifers found there are composed of three superimposed reservoirs: i) at the top, there are alterations which are composed of lateritic cuirass, clay, arena when the geological formations are of granitoid type. In the region, these alterations are predominantly clay. ii) The middle zone is made up of rock elements and alteration products, with or without the presence of numerous cracks. This zone, when containing water, is the main reservoir of the basement aquifer. iii) The third reservoir is located in fractured basement. It is covered by simple fractures or in some cases by crushed areas due to fairly strong local stresses. This base tank is often the seat of groundwater circulation. The three reservoirs are in fact considered as a bilayer aquifer system consisting of a capacitive semipermeable reservoir (alterites) overhanging a reservoir 
International Journal of Environment, Agriculture and Biotechnology, 5(4)

Jul-Aug, 2020 / Available: https://ijeab.com/

formed of cracked rock, captive with essentially conductive function.

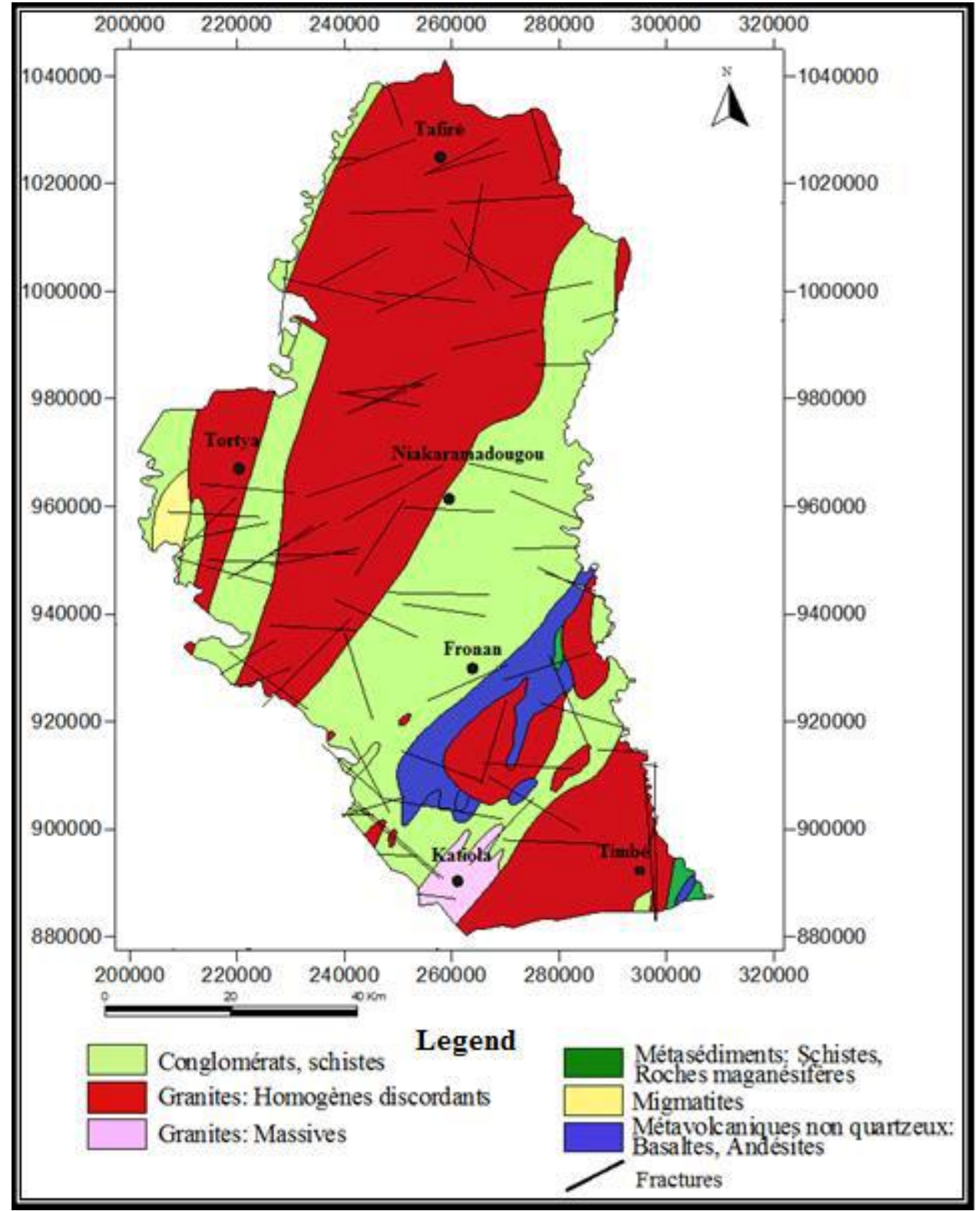

Fig. 3. Geological map of the area study

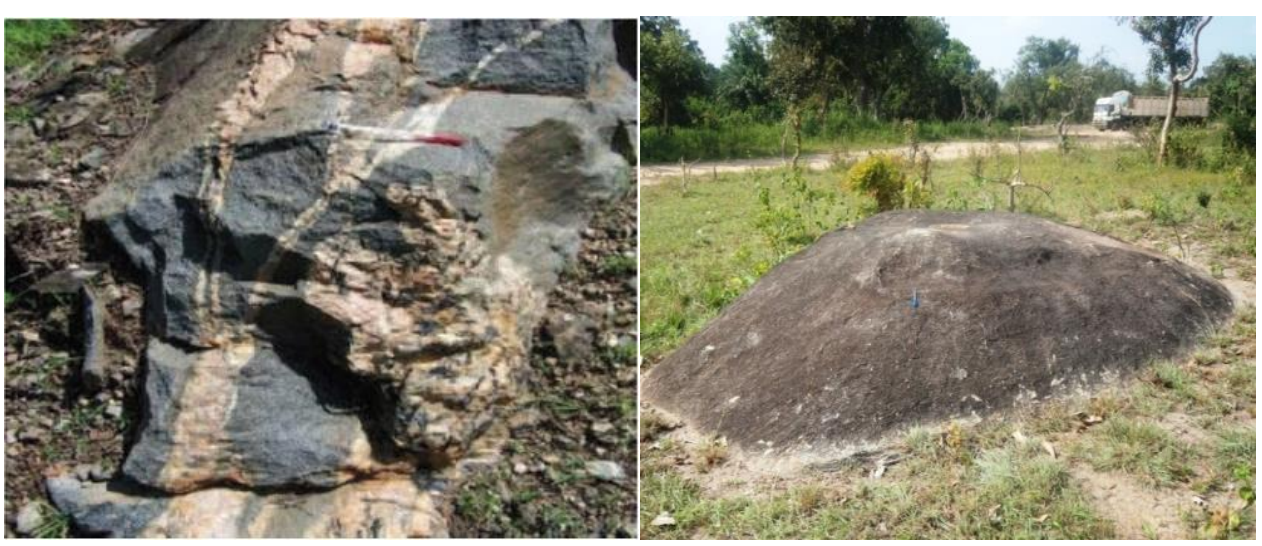

4a) Outcrops of granite and metavolcanite 


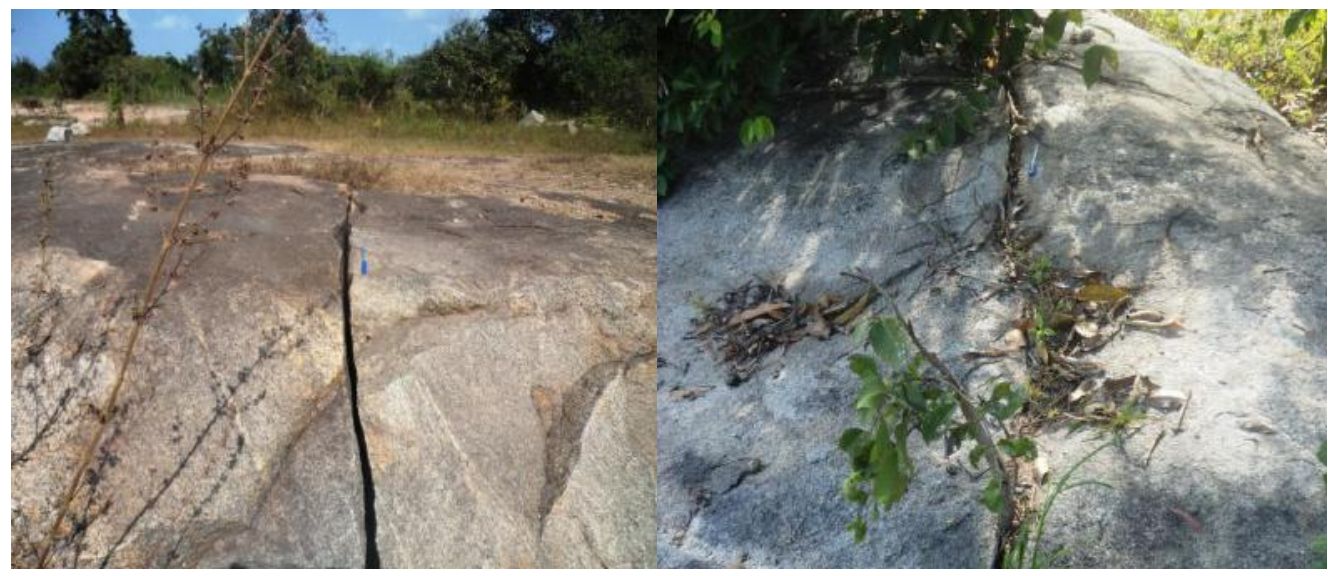

4b) Fractures of NE-SW direction

Fig.4.(a, b). Some outcrops and fractures identified during the field campaign

\section{MATERIAL AND METHOD}

\subsection{Data analysis}

The data used consists of a RADARSAT-1 scene for the mapping of major lineaments, the characteristics of which have been recorded in Table 1. Unlike optical images, radar or (Radio Detection And Ranging) images allow to visualize large areas, under various atmospheric conditions. Indeed, radar is a measuring system that makes it possible to observe terrestrial areas regardless of the weather conditions due to the penetration of electromagnetic waves through the cloud cover (Bouchemakh et al., 2011). In addition, we used end-ofdrilling production flow data from nearly 100 boreholes in a village hydraulics programme to study the relationship between productivity and fracturing extracted from satellite images.

Table 1 : Some characteristics of the RADAR scene

\begin{tabular}{|l|c|}
\hline \multicolumn{2}{|c|}{ Characteristics } \\
\hline System & RADARSAT-1 \\
\hline Wave length & $5,66 \mathrm{~cm}$ \\
\hline Frequency & $5,3 \mathrm{GHz}$ \\
\hline Spectral Band & $3,75-7,5 \mathrm{~cm}$ \\
\hline Spatiale resolution & $50 \mathrm{~m}$ \\
\hline
\end{tabular}

\subsection{Method}

\subsubsection{Method of major fractures determination}

Lineament processing and extraction was performed using ENVI 4.3 (Environment for visualising image) software. Several spatial filters were used to enhance the radar image and plot the structural lineaments, these were, i) the modified 5x5 Laplacian filter. This is a non-directional filter that enhances the contours of the image components, ii) the $7 \times 7$ Sobel filter (assigned with weight 6) in the N-S, E-W, NE-SW and NW-SE directions. This filter shows the lineaments perpendicular to their convolution direction
(Figure 5). On the processed images, the discontinuitiesimages corresponding to supposed structural lineaments were recorded manually, following a visual analysis on the screen. This consisted of representing by a right segment the discontinuities-images and abrupt changes in tone observed on the images. All these extraction operations have resulted in a detailed linear map of the study area.We have extracted the major lineaments map taking into account lineaments larger than $12 \mathrm{~km}$. Lineament validation is carried out on the basis of fracture data measured at outcrops at various sites and fracture data taken from geological maps. 


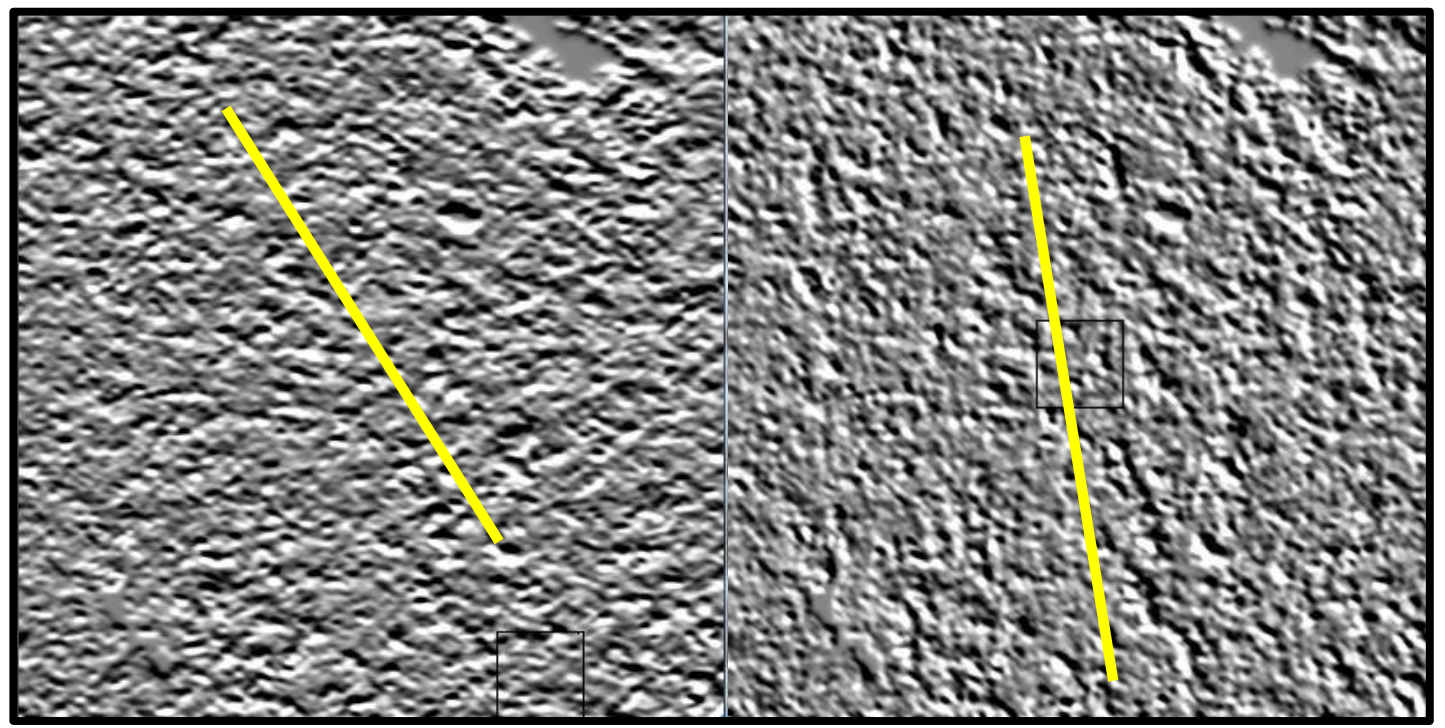

Fig.4. Radar image enhanced with Sobel filter (7 $x 7)$ showing fractures

\subsubsection{Calculation method of production flows}

The production flows exploited were obtained during short-term test pumping, also known as well testing on isolated boreholes with multiple flow bearings. The minimum number of bearings required to achieve satisfactory results is 3 and the purpose of these tests is to determine the characteristics of the well to deduce the maximum performance of the structure (CIEH, 1978). The tests were carried out by successive short-term pumping with increasing flow rates. Borehole flow rates were measured at capacity for a given filling time, the time being measured using a stopwatch or a handle watch (volumetric method or low-flow measurement method per tank). When the capacity is of sufficient volume and the water is well channelled, the accuracy of the flow measurement is satisfactory (Faillat, 1986). The following formula is then used:

$$
Q=\frac{v}{t}
$$

3.2.2. Study of relationship between major fractures and productivity of boreholes

The analysis of the relationship between the productivity of the works realized and the lineaments was carried out from different maps. Spatial interpolation flow maps were generated from GIS software, ARCVIEW GIS 3.2 of
Environmental Systems Research Institute, Inc, (19921999) and SURFER 9.0. These different maps were superimposed (overlayed) in the same plane with the spatial distribution of major fractures to assess the link between these different parameters. Statistical tests generated from Excel made it possible to analysis the influence of major accidents in the positioning of boreholes.

\section{RESULTS AND DISCUSSION}

\subsection{Results}

\subsubsection{Analysis of major fractures network}

The fracture network map was used to extract largeextension fractures that we considered major fractures (multi-kilometric fractures). There are 323 lineaments identified. These major fractures account for more than $12 \%$ of overall fracturing and have spread across the entire study region, but have a relatively smaller distribution in the western sector, at the Tortiya level. Some major lineaments have boundaries that extend beyond the region (Figure 5). The analysis of the map also shows that their large size promotes their interconnection, we see nodes of two or more fractures, which is likely to facilitate the formation of good aquifers. 


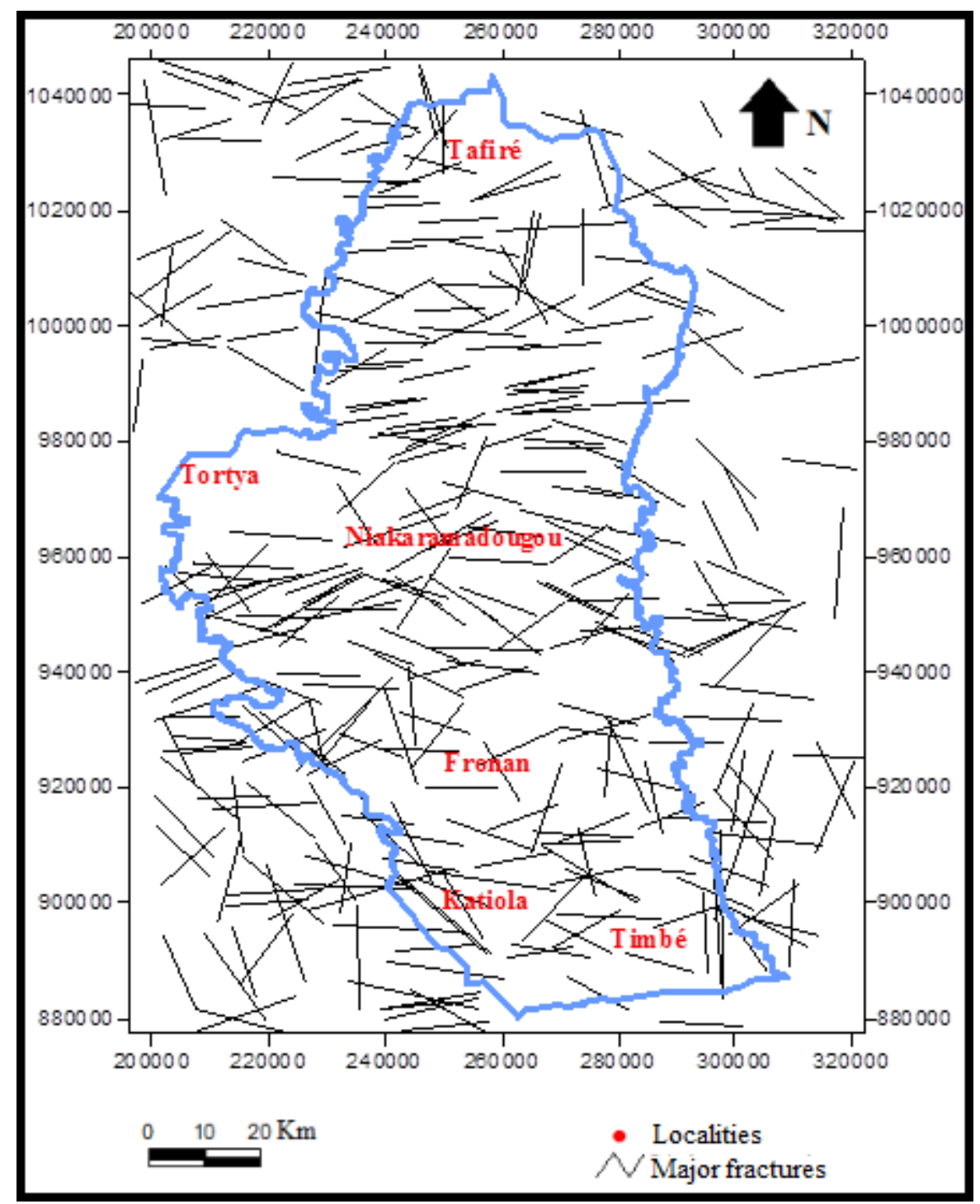

Fig.5. Lineaments major map of Katiola

\subsubsection{Statistical analysis of major fractures length}

Examination of the table of statistical elements of fracturing shows that the size of the lineaments varies from 12 to about $32 \mathrm{~km}$ with an average value of 15.13 $\mathrm{km}$. The class distribution histogram in Figure 6 indicates that most major lineaments $(50 \%)$ have lengths between 12 and $14 \mathrm{~km}$. We also note that $20 \%$ have lengths between 14 and $16 \mathrm{~km}$. The coefficient of variation value $\mathrm{Cv}(21 \%)$ confirms the low heterogeneity in the distribution of major fracture lengths.

Table II : Statistical parameters of major fractures

\begin{tabular}{lccccc}
\hline Parameters & Number & Average & Minimum & Maximum & Standard deviation \\
\hline Major fractures length $(\mathrm{km})$ & 323 & 15,13 & 12 & 31,86 & 3,23 \\
\hline
\end{tabular}




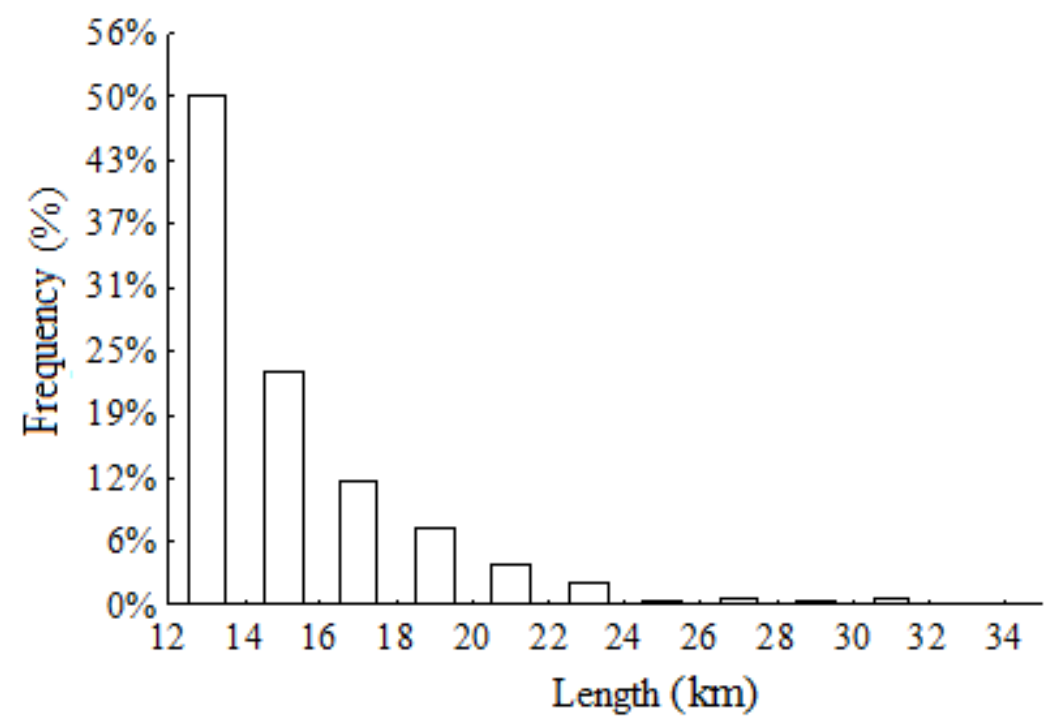

Fig.6. histogram of major lineaments length distribution

\subsubsection{Orientation of major fractures distribution}

The distribution diagram of major lineaments orientations shows a variability of mega-fracture directional classes $(\%$ of frequencies per class of 10\%). The N90-100 directional class is the main one with $14 \%$, followed by the N70-80, N100-110 and N80-90 classes that stand out from the others (Figure 7). There are the directions of secondary mega-fractures. The other classes are minority with frequencies sometimes below 5\%. Thus, the N30-40 and N40-50 classes are the least represented with respectively 2 and $3 \%$ frequency.

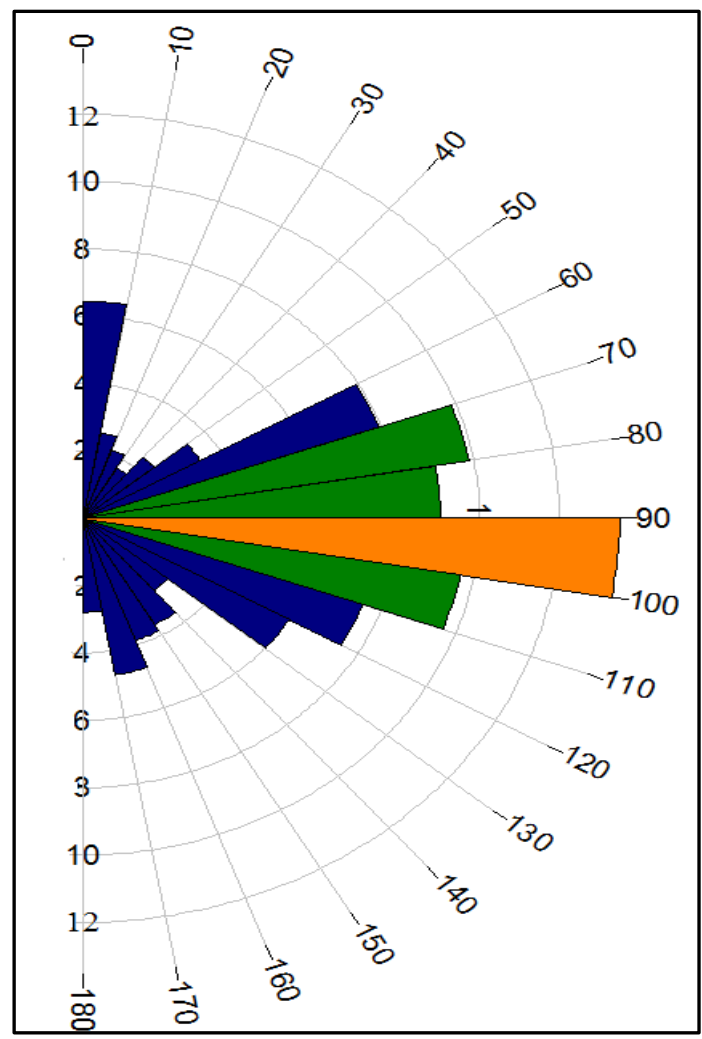

Fig.7. Rose diagram in number of major fractures 


\subsubsection{Spatial distribution of boreholes flow}

Figure 8 represent the spatial distribution map of borehole production flows in Katiola region. Analysis of this map shows any spatialization of the borehole flow classes. The analysis of this map shows any spatialization of the borehole flow classes. We also noted that low flows are spread throughout the region. Medium and high flows are found mainly in the central and southern part of the region. Medium and high flows are found mainly in the central and southern part of the region.
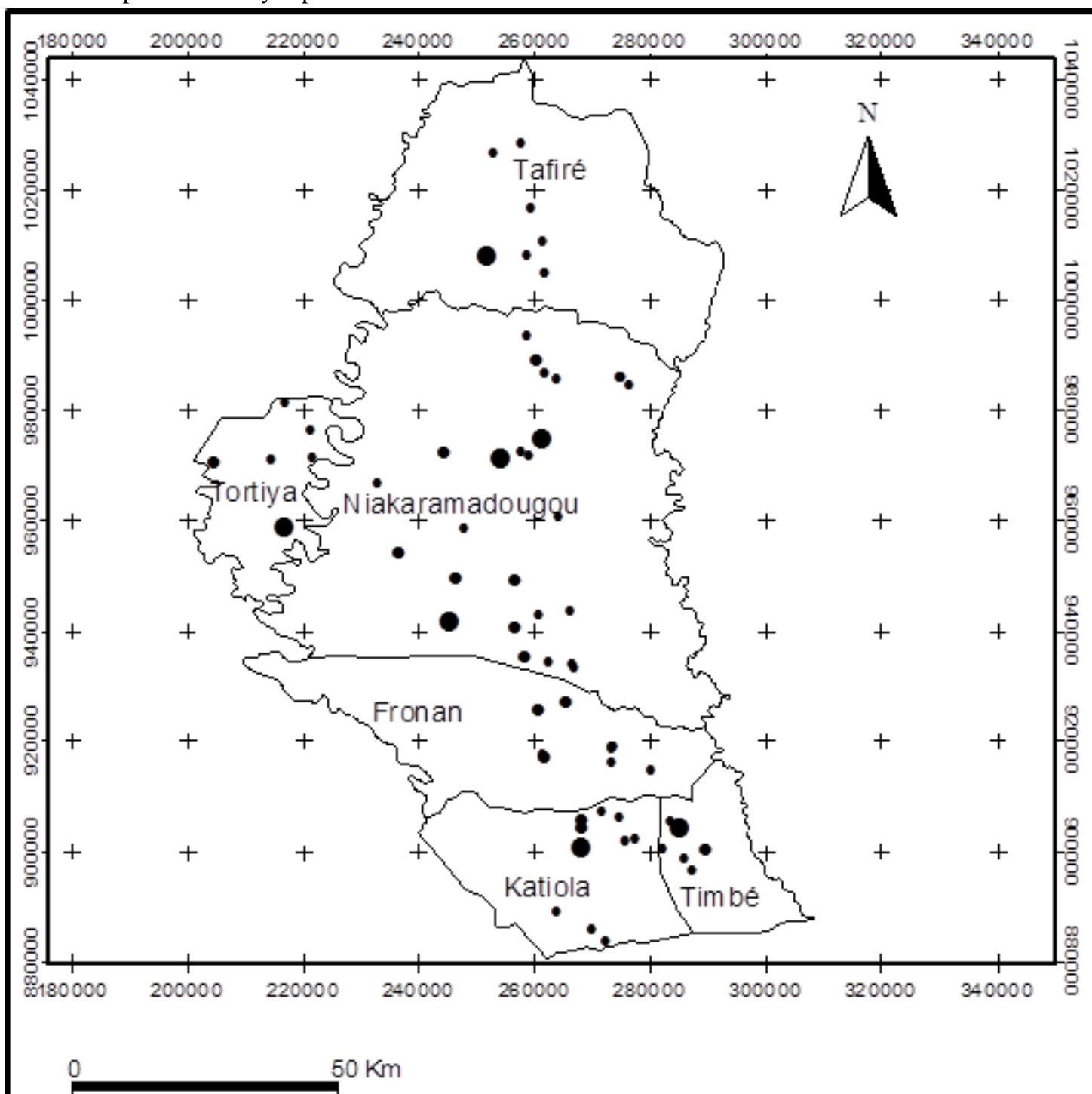

Legend

\begin{tabular}{|l|ll}
\hline & \multicolumn{3}{|c}{ Sub-prefectures limits } \\
& Class of flows (m3/h) \\
- & $0-2.5$ & Low flows \\
- & $2.5-5$ & Medium flows \\
- & $5-15$ & High flows
\end{tabular}

Fig.8. Distribution map of flow classes 


\subsubsection{Analysis of spatial distribution map of boreholes flow and major fractures}

Analysis of the spatial distribution map (Figure 9) indicates that the boreholes with low and medium flow do not overlap with major fractures. Moreover, they are unlikely to have any particular organization in comparison with them. This may account for the high proportion of low- flow boreholes in the study area. However, the map show a few boreholes located either near these major accidents or intersecting major and interconnected fractures (the northern and southern part of the region). It should be noted that these boreholes offer the most interesting flows in this category.

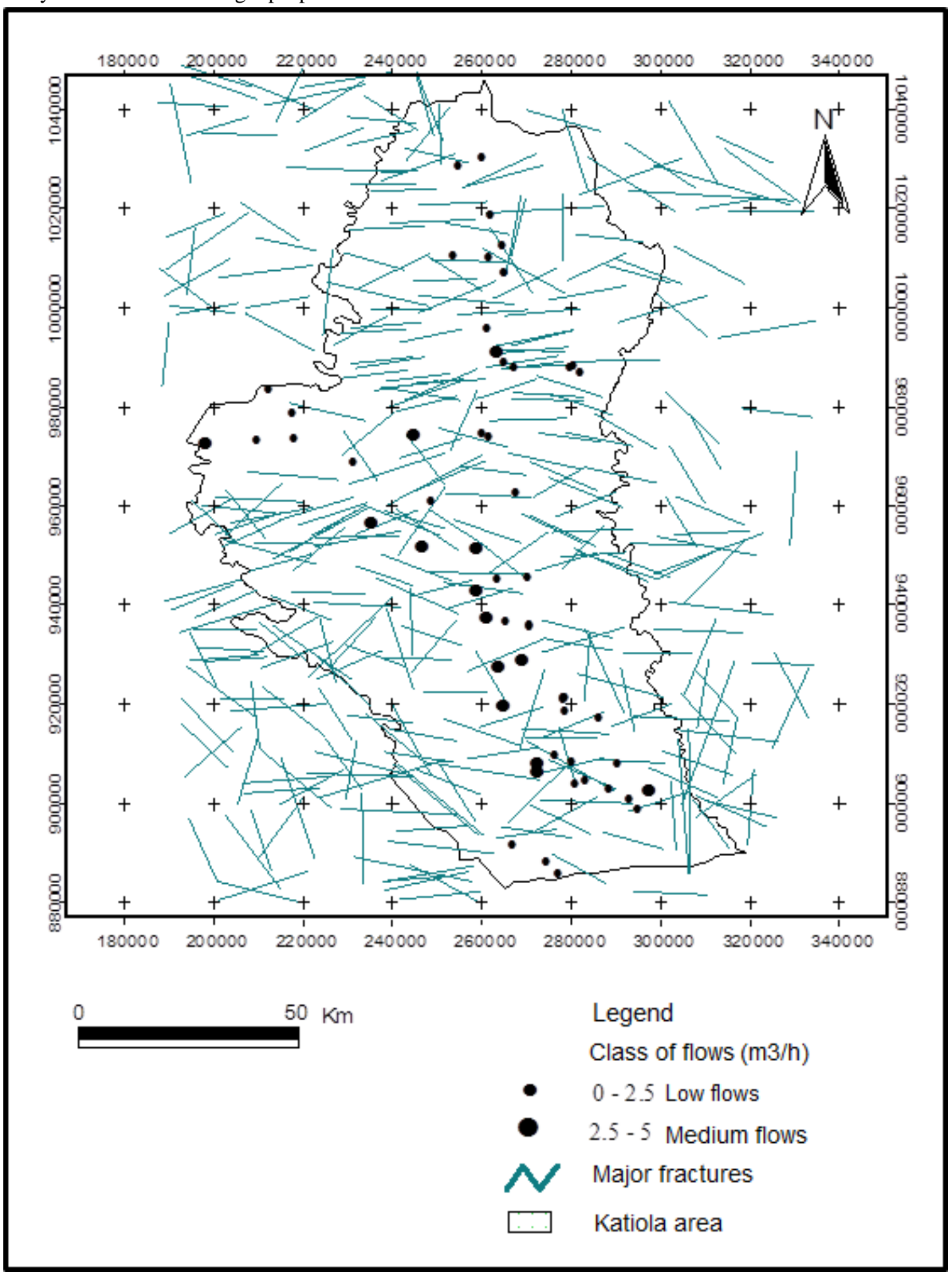

Fig.9. Overlay map of low and medium flows and major fractures 


\subsubsection{Analysis of spatial distribution map of boreholes high flow and major fractures}

Analysis of the spatial overlay map of the high flows with the mega fractures reveals an interesting finding. All high boreholes flow are overlap or very close to major fractures and most often interconnected (figure 10). The Kafiné point (245839.7: 941122) in the figure with the largest flow $\left(14.5 \mathrm{~m}^{3} / \mathrm{h}\right)$ is quite illustrative, as is Kolokaha (252202.19:1006993) with $\left(9.5 \mathrm{~m}^{3} / \mathrm{h}\right)$ and Zanakaha (217239.19: 957737.19) with $\left(9.2 \mathrm{~m}^{3} / \mathrm{h}\right)$. All this confirms the predominant role of open fractures and their connectivity in the formation of good aquifers in the fractured basement of Katiola region.

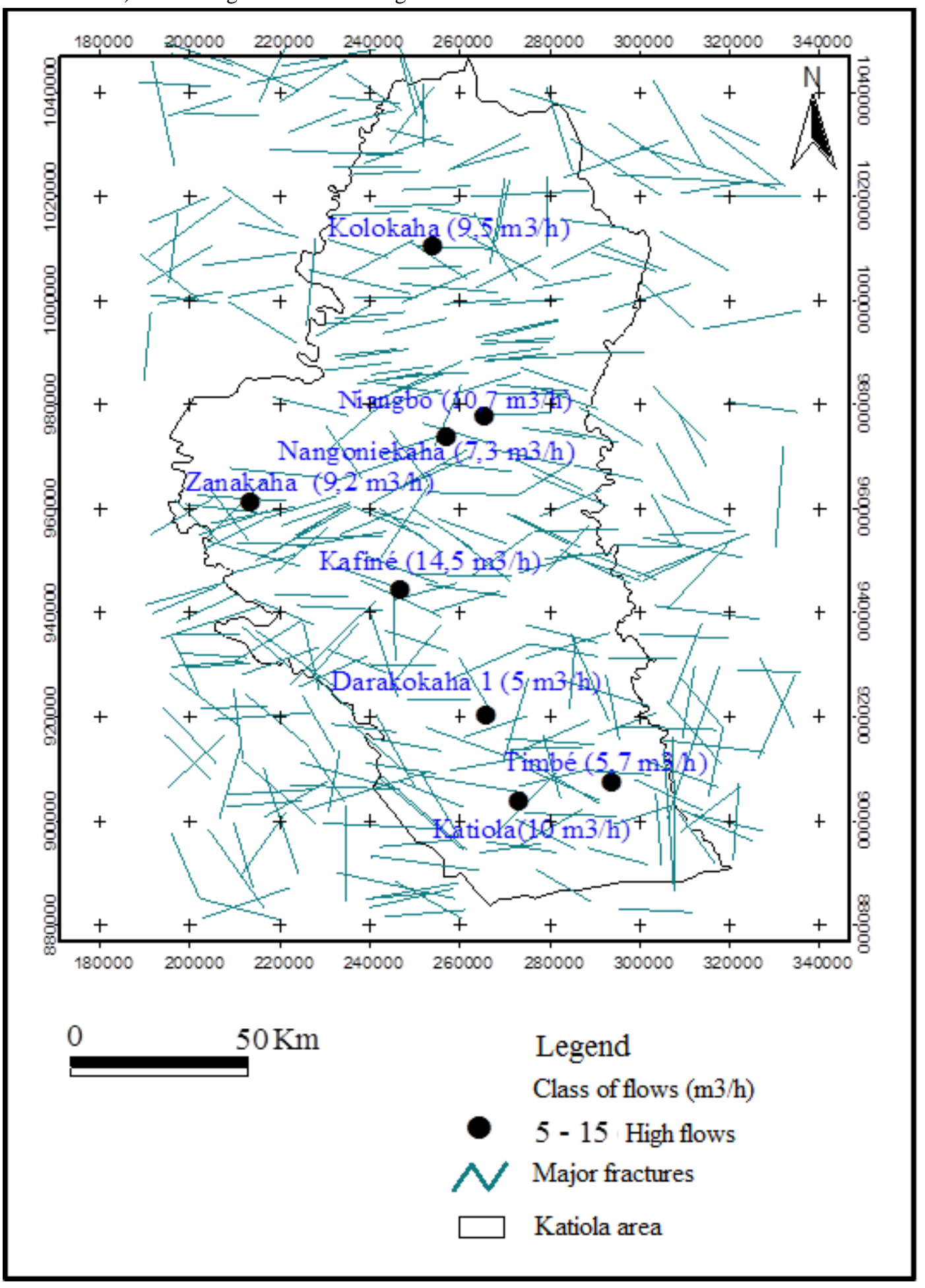

Fig.10. Overlay map of high flows and major fractures 
3.1.6. Statistical analysis of the correlation between borehole flow rate and their distance from major lineaments

The statistical analysis of boreholes flows evolution (strong and low) in relation to their distances to nearest lineaments is given by the different graphs in the figure 11. It reveals a clear influence of the distance between boreholes and lineaments on the flow rate evolution. Indeed, we note that the highest proportion ( $88 \%$ ) of the flows of structures in the right of a fracture (capturing directly a fracture) is located at the level of the high flows, come next the medium flows (31\%) and the low flows (25\%). However, at the level of boreholes relatively distant from major fractures, it is paradoxically, the low flow structures that take the lead with more than $75 \%$, followed by medium flows $(69 \%)$ and less than $10 \%$ for high throughputs. The flow therefore evolves in inverse proportion according to the distance between fractures and boreholes.

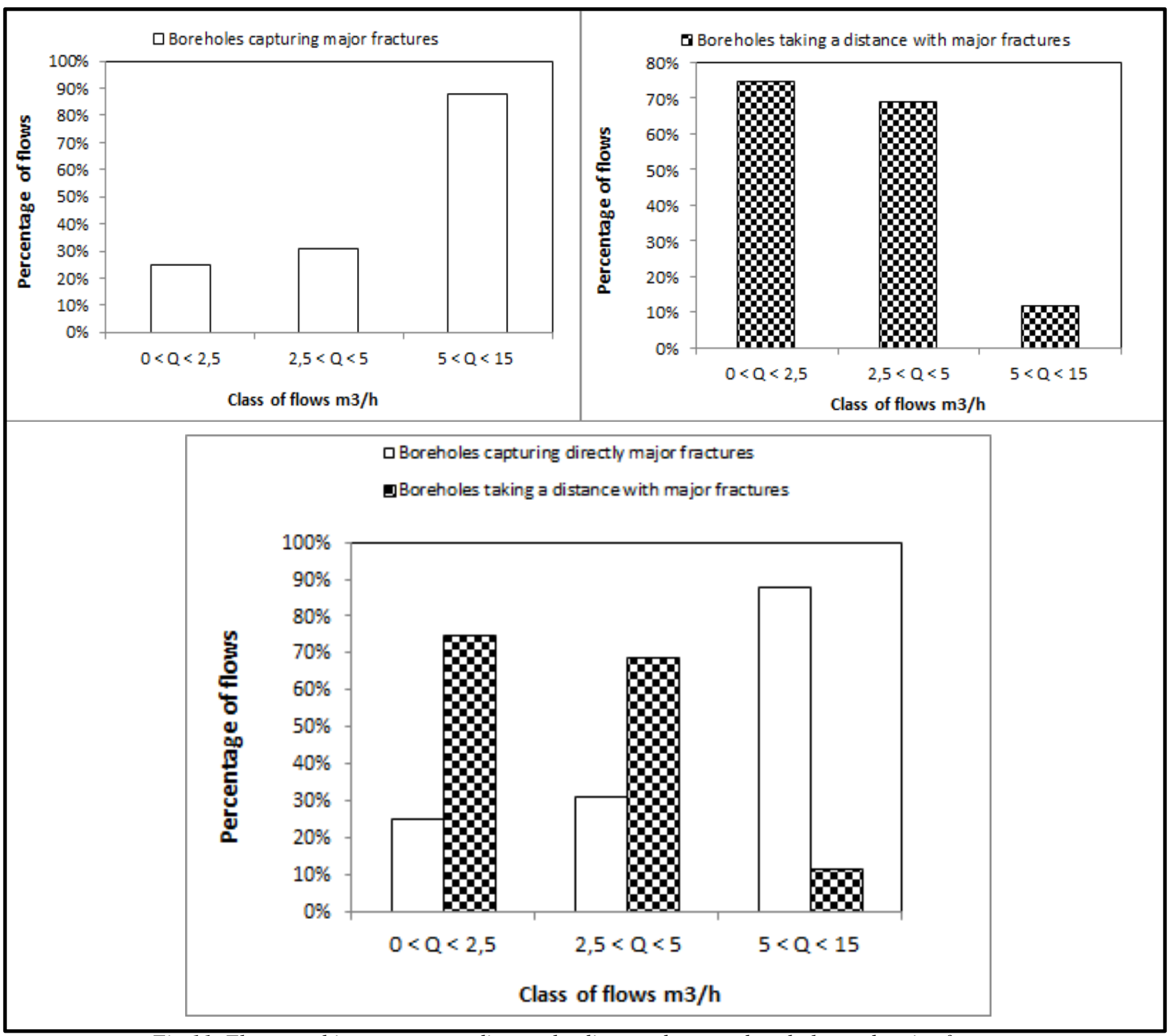

Fig.11. Flow rate histogram according to the distance between boreholes and major fractures

3.1.6. Regression of boreholes percentages according to their relative distance to major accidents

The study of the influence of the positioning of the fractures or their relative distances with the boreholes is completed by the curve of decay of the figure (12). The analysis of the figure corroborates the observations made earlier, namely the influence of the distance between the major lineaments and boreholes on the productivity of the structures. It allows you to make a few comments on the graph, which looks like 3 parts: 
- a straight line of ideal settlements located on the ordinate-axis representing $40 \%$ of the holes drilled that directly capture a fracture in the basement of the region. This is the category of drillings offering the best production flows;

- a rapid decay curve between 0 and $2000 \mathrm{~m}$ with a peak at $1000 \mathrm{~m}$. It corresponds to the curve of the boreholes closest to the fractures with flow varying between $0.6 \mathrm{~m}^{3} / \mathrm{h}$ and $10 \mathrm{~m}^{3} / \mathrm{h}$. This decrease indicates that the further one moves away from the fracture, more the probability of having a good borehole flow decreases. The $1000 \mathrm{~m}$ distance between boreholes and lineaments would represent the threshold not to be crossed;

- a relatively moderate decrease curve between 2000 and 8000, it corresponds to the most distant boreholes from fractures with $30 \%$ of the number wells. It is the class of boreholes offering the lowest flows in the region varying between $0.4 \mathrm{~m}^{3} / \mathrm{h}$ and $3.8 \mathrm{~m}^{3} / \mathrm{h}$.

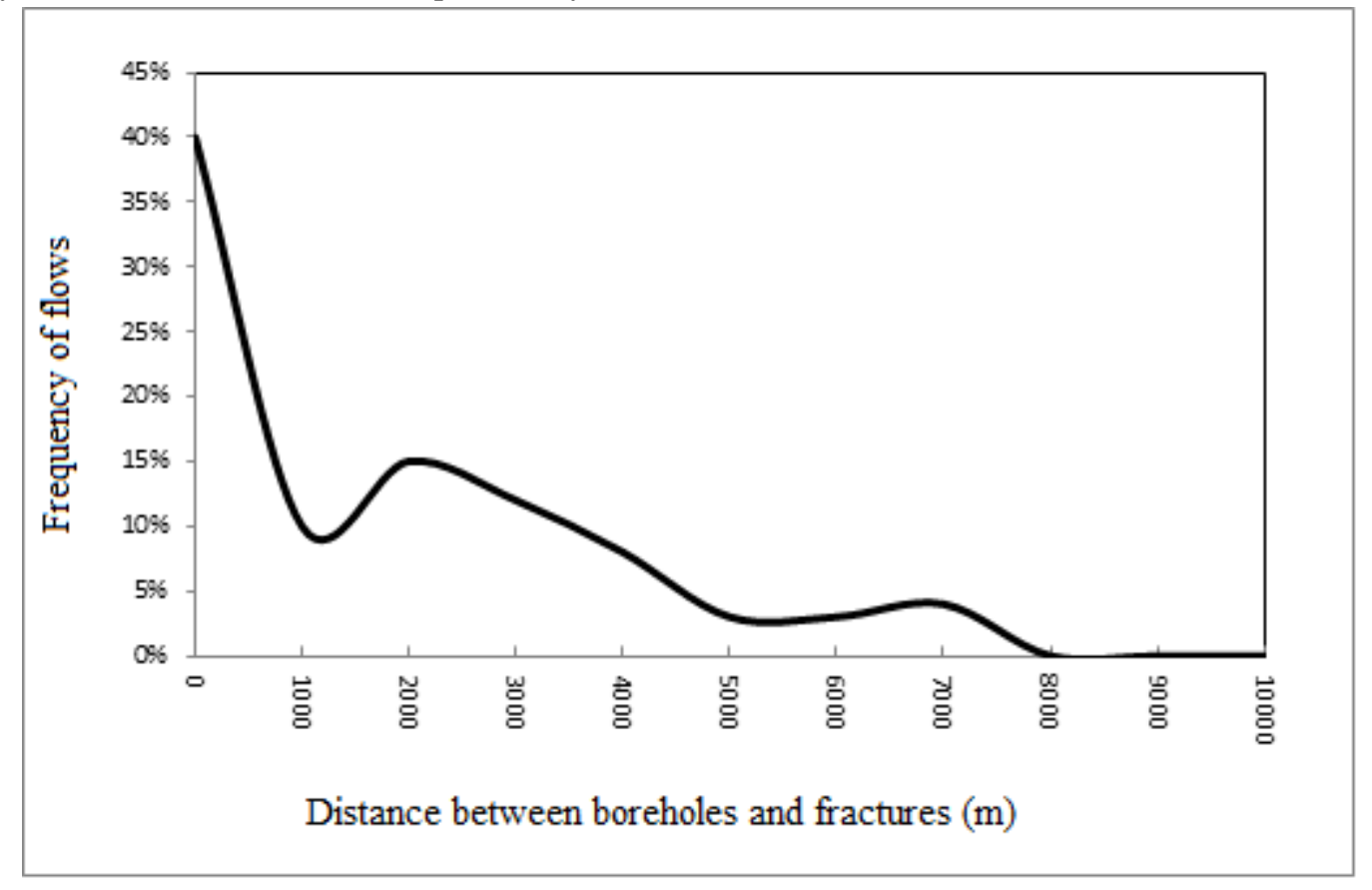

Fig.12. Flow rate histogram according to the distance between boreholes and major fractures

\subsection{Discussion}

Many works in recent decades have shown that to locate suitable well sites in the environment of the crystalline basement, it is necessary to use satellite images or aerial photography to locate and map fracture traces on the roof of the base (savané, 1997). In Katiola region, the major accidents which also constitute preferential groundwater flow corridors follow the following predominant directions: N90-100, followed by N70-80, N80-90 and N100-110. These main directions are more or less similar to those obtained by Jourda (2005) in Korhogo area and Biémi (1992) in Séguéla region, both close to the study area. The different preferential directions of tectonic accidents identified by their work are (N170-190; N30-40; N90-100; N120-130; N140-160; N60-80). It should be noted that, in general, the major lineaments detected are distributed according to the four main tectonic directions of Africa (N30-60; N80-100; N120-160; N170-190). The
N90-100 class being the direction with the most major accidents with $14 \%$ of fractures, corresponds according to their work to fairly discrete accidents and not too visible in the field. According to Biémi (1992), these accidents are discontinuous in satellite images, probably due to the frequent influence of other break directions that cut them by shifting them.

Wells dug to the right of these fractures, or better still where two or more fractures intersect, generally provide a large flow of groundwater (Setzer, 1966; Siddiqui and Parizek, 1971). According to Kouadio et al (2008), the search for groundwater in basement environments is essentially based on the identification of fractures that are witnesses to tectonic deformations. Thus, a borehole that does not cross any fracture cannot produce water. The results of the analysis of the influence of major accidents on the positioning and productivity of boreholes in the Katiola region corroborate these assertions. It emerges 
from our work that the majority of low flow rates rarely exceeding $1 \mathrm{~m}^{3} / \mathrm{h}$ are not located on megafractures, or are for some in the vicinity of such megafractures. For many authors, the boreholes drilled as part of national village hydraulics programmes are largely based on subjective investigations such as geomorphology to the detriment of advanced methods such as geophysics or remote sensing (Faillat, 1986; Biémi, 1992; Gombert, 1997; Saley, 2003; Jourda, 2005; N'Go et al., 2010, Mangoua et al., 2019). This observation partly justifies the low flows obtained or the very often high failure rate during the implementation of the structures, which can locally exceed $50 \%$ in discontinuous basement aquifers according to Gombert (1997). In katiola region, the spatial distribution of the flow classes shows a predominance of modest flows on a regional scale. Assemian et al (2014) find similar results in the Bongouanou basement. Moreover, according to Savané (1997), although the number of boreholes drilled during national hydraulic campaigns is significant, borehole flows generally remain low ( 1.5 to $2 \mathrm{~m}^{3} / \mathrm{h}$ ) for a drawdown equal to $12 \mathrm{~m}$ in the arenas, 5 to $1 \mathrm{~m}^{3} / \mathrm{h}$ for a drawdown equal to $20 \mathrm{~m}$ in the Birrimian formations.

The overlaying map of major lineaments with the large flows gives quite evocative results. Most borehole points are located at the right of two or even several major fractures. This result corroborates the interest of well-filled and interconnected aquifer discontinuities in the search for large flows in fractured basement environments (Gombert, 1997). According to Engalenc (1979, 1981), one of the main criteria often used in the siting of boreholes in basement environments is: the site must be in a crossing of the longest, cleanest and, if possible, most numerous fractures. In crystalline rocks, the fracture zones and the fracture intersection point are usually the only sites where groundwater is entering. They form an intercalated network of high transmissivity and act as a conduit for groundwater from massive rocks in the interfracture domains (Savané, 1997). However, if the underlying bedrock is resistant to weathering and erosion, it may have several open fractures, but little groundwater can be captured by the well. Therefore, the expected productivity would be small. This could justify the lower air lift flows sometimes observed in some areas even though the well is implanted at the right of a major fracture (south and north of the region).

The results of our work also indicate that the flow rate is inversely proportional to the distance between major accidents and fractures, but not linearly. These results are similar to those of Baka et al (2019) in Oumé region, Koita et al (2010) region of Dimbokro-Bondoukou, Savané (1997) in Odienné region. All this confirms that these vertical or subvertical accidents of the basement have an influence on the hydrodynamic behaviour of the basement aquifers of the Katiola region.

\section{CONCLUSION}

This study established the link between the productivity of boreholes at the end of drilling and the discontinuities detected as lineaments in Katiola region. It thus appears from this work that the major preferential directions for groundwater circulation in the area are; N90-100, N70-80, N100-110 and N80-90. The major fractures detected are distributed according to the four main tectonic directions of Africa. Several boreholes with low flows $0<\mathrm{Q}<2.5 \mathrm{~m}^{3} / \mathrm{h}$ ) do not overlap with the major structural lineaments detected and seem to have been drilled using a simple geomorphological criteria, which would justify the low flows observed in most of the works carried out. All high flow boreholes $\left(\mathrm{Q} \geq 5 \mathrm{~m}^{3} / \mathrm{h}\right)$ match and overlap with open and interconnected fractures. The distance between major accidents and the boreholes influences the productivity of the works carried out. These results indicate that fracture arrangement and degree interconnection play an important role in the storage and conduct properties of aquifer systems in the region. The approach used in this study may be an indirect means of validating the map of the major fractures network that can be used in future drilling campaigns in the Katiola region.

\section{REFERENCES}

[1] Assemien A.E., Kouamé K.F., Saley M.B., Affian K., Younta Ta M., Jourda J.P.R. et Biémi J. (2014). Étude de la productivité d'un aquifère de socle et approche statistique pour la détermination des tranches de profondeurs potentiellement productives : cas de la région de Bongouanou, est de la Côte d'Ivoire. Revue des sciences de l'eau / Journal of Water Science, 27 (1), pp. 81-97.

[2] Baka D., Gnamba F.M., Yao K.T. et Youan Ta M. (201). Influence des caractéristiques de l'aquifère sur la productivité des forages dans la région d'oumé (centre-ouest côte d'ivoire). Asian Journal of Science and Technology Vol. 10, Issue, 08, pp. 10005-10013.

[3] Bassolé A., J. Brunner et D. TUNSTALL (2001). SIG et appui à la planification et à la gestion de l'environnement en Afrique de l'Ouest. Rapport de synthèse, World Resources Institute, $48 \mathrm{p}$.

[4] Biémi J. (1992). Contribution à l'étude géologique, hydrogéologique et par télédétection des bassins versants subsaheliens du socle précambrien d'Afrique de l'Ouest : Hydrostructurale hydrodynamique, hydrochimique et isotopie des aquifères discontinus de sillons et aire granitique de la Haute Marahoué (Côte d'Ivoire). Thèse de 
Doctorat ès Sciences Naturelles, Université d'Abidjan, Côte d'Ivoire $479 \mathrm{p}$.

[5] Biémi, J. (1997) Positionnement, productivité et gestion des forages en milieu fissuré de Côte d'Ivoire par télédétection et système d'information géographique. Atelier de la FAO sur Télédétection et ressources en eau, Montpellier. Séries Water Report $16 . \quad$ Available from http://www.fao.org/docrep/w7320b18.htm [Google Scholar]

[6] Bouchemakh L., Boutarfa S., Smara Y. et Souissi B. (2011). Sur le filtrage du chatoiement dans les images radar SAR polarimétriques: Etude des régions d'Alger et d'Oran. Revue Télédétection, 2011, vol. 10, pp. 113-127.

[7] CIEH (1978). Méthode d'étude et de recherche de l'eau souterraine des roches cristallines de l'Afrique de l'Ouest. Edition Géohydraulique, vol. 1, 190p.

[8] Dewandel B., P. Lachassagne, R. wyns, J.C. Maréchal et N.S. Krishnamurthy (2006). A generalized 3-D geological and hydrogeological conceptual model of granite aquifers controlled by single or multiphase weathering. J. Hydrol., 330, pp. 260- 284.

[9] Engalenc M. (1979). Méthode d'étude et de recherche de l'eau souterraine des roches cristallines de l'Afrique de l'Ouest Géohydraulique CIEH. 194 p.

[10] Engalenc M. (1981). Elément de quantification des ressources hydrauliques dans les roches cristallines. Bulletin B.R.G.M., Série II, Section III, n ${ }^{\circ}$ 4, pp. 325-326.

[11] Faillat J. P. (1986) « Aquifères fissurés en zone tropicale humide: structure, hydrodynamique et hydrochimie (Afrique de l'Ouest) ", Thèse Université. Languedoc (Montpellier), $534 \mathrm{p}$.

[12] Faillat J.P. (1986 a). Hétérogénéité et effet d'échelle dans les aquifères fissurés. Approche par pompage d'essai sur station expérimentale (Afrique de l'Ouest). Hydrogéologie, n. ${ }^{\circ} 1$, pp. 65-76.

[13] Fernandes, A.J. et Rudolph, D.L., 2001. The influence of Cenozoic tectonics on the groundwater-production capacity of fractured zones: a case study in Sao Paulo, Brazil. Hydrogeol. J., 9: pp. 151-167.

[14] Gnamba F.M. (2014). Hydrochimie et hydrodynamisme des réservoirs de fissures du socle paléoprotérozoïque de la région de Katiola. Thèse de Doctorat, Université Félix Houphouët Boigny, Côte d'Ivoire, 200 p.

[15] Gnamba F.M., Oga Y.M.S., Gnagne T., Lasm.T., Biémi J. et Kouakou Y.K.N (2014). Analyse de la productivité des aquifères de fissures du socle paléoprotérozô̂que de la région de Katiola: (Centre-Nord de la Côte d'Ivoire). European Scientific Journal February 2014 edition, vol.10, No.5, pp. 79-98.

[16] Gombert P. (1997). Variabilité spatiale de la productivité aquifère du socle sahélien en hydraulique rurale. Hard Rock Hydrosystems, IAHS Publ., Vol. 241, pp. 113-122.

[17] Jourda J.P.R. (2005). Méthodologie d'application des techniques de télédétection et des systèmes d'information géographique à l'étude des aquifères fissurés d'Afrique de l'Ouest. Concept de l'hydrotechnique spatiale : cas des zones tests de la Côte d'Ivoire. Thèse de Doctorat d'Etat, Université de Cocody-Abidjan, Côte d'Ivoire, 430p.

[18] Koita M., Jourde H., Ruelland D., Koffi K., Pistre S. et Savane I. (2010). Cartographie des accidents régionaux et identification de leur rôle dans l'hydrodynamique souterraine en zone de socle. Cas de la région de DimbokroBongouanou (Côte d'Ivoire), Hydrological Sciences Journal, 55(5), pp. 805-820.

[19] Kouamé K.F. (1999). Hydrogéologie des aquifères discontinus de la région semimontagneuse de Man-Danané (Ouest de la Côte d'Ivoire). Apport des données des images satellitaires. Thèse de Doctorat, Université Cocody-Abidjan, Côte d'Ivoire , $194 \mathrm{p}$.

[20] Kouame K. F., Akaffou A. G., Lasm T., DE Dreuzy J. R., Davy P. et Bour O. (2005): Simulation des écoulements dans les réservoirs fracturés: Application au socle archéen de Touba (Nord-Ouest de la Côte d'Ivoire). Actes du Colloque Internationale SITIS 05 Yaoundé(Cameroun) 27 Nov.-1er Déc. 2005. pp. 39-46.

[21] Kouamé, K. F., Lasm, T., De Dreuzy, J. R., Akaffou, A. G., Bour, O. et Davy, P. (2010). Contribution d'un modèle hydrogéologique à fractures discrètes à l'étude des aquifères fracturés du socle Archéen de Touba (Nord-Ouest, Côte d'Ivoire). Revue des sciences de l'eau / Journal of Water Science, 23 (1), pp. 41-56.

[22] Larsson I., 1972. Ground water in granite rocks and tectonic models. Nordic Hydrology, 3: pp. 111-129.

[23] Lasm T., Fossou R.M.N, Onetie O.Z., Baka D., Youan TA M., Marie Solange OGA M.S. et SORO N. (2012). Contribution hydrogéologique à la connaissance des aquifères discontinus du département de ferké (nord de la côte d'ivoire) pour une meilleure alimentation en eau potable. Rev. Ivoir. Sci. Technol., 19 (2012) pp.114 - 135.

[24] Mangoua M.J., Yao A.B., Douagui G.A., Kouassi K.A., Goula B.T.A. et BIEMI J. (2019). Evaluation des potentialités en eau souterraines des aquifères fissurés dans le bassin versant du Bandama (Côte d'Ivoire), Larhyss Journal, n³7, pp. 53-74.

[25] Maréchal J.C., B. Dewandel, S. Ahmed, L. Galeazzi et F.K. Zaidi (2006). Combined estimation of specific yield and natural recharge in a semi-arid groundwater basin with irrigated agriculture. J. Hydrol., 329, pp. 281-293.

[26] Naik, P.K., Awasthi, A.K., Anand, A.V.S.S., Mohan, P.C., 2001. Hydrogeologic framework of the Deccan terrain of the Koyna River basin, India. Hydrogeol. J., 9(3): pp. 243-264.

[27] Neves, M.A., Morales, N., 2007. Structural control over well productivity in the Jundiaí River catchment, Southeastern Brazil. Anais da Academia Brasileira de Ciências, 79(2): pp. 307-320.

[28] N'Go Y.A., Lasm T., Koita M. et Savane I. (2010). Extraction par télédétection des réseaux de fractures majeures du socle précambrien de la région de Dimbokro (Centre Est de la Côte d'Ivoire). Télédétection, Vol. 9, $\mathrm{N}^{\circ} 1$, pp. 33-42.

[29] RGPH. (2014). Récensement Générale de la population et de l'Habitat 2014, Résultats Globaux, 22 p. 
[30] Roques C. (2013). Hydrogéologie des zones de faille du socle cristallin : implications en terme de ressources en eau pour le Massif Armoricain. Thèse de Doctorat ès Sciences Naturelles, Université de Rennes, France, 238 p.

[31] Saley M.B. (2003). Système d'informations à référence spatiale, discontinuités pseudoimages et cartographies thématiques des ressources en eau de la région semimontagneuse de Man (Ouest de la Côte d'Ivoire). Thèse unique de doctorat, Université de Cocody, 209 p.

[32] Savané I. (1997). Contribution à l'étude géologique et hydrogéologique des aquifères discontinus du socle cristallin d'Odienné (Nord-Ouest de la Côte d'Ivoire). Apports de la télédétection et d'un Système d'Information Hydrogéologique à Référence Spatiale. Thèse d'État, Univ. Abidjan, Côte d'Ivoire, 386 p.

[33] Setzer 1, 1966. Hydrologic significance of tectonic fractures detectable on air photo. Groundwater. Vol. 4 pp 23-29.

[34] Siddiqui S.H., Parizek R.R., 1971. Hydrologie foctors influencing well yields in folded and faulted carbonate rock in central pennsylvania. Water Resources Research, Vol. 7 $\mathrm{N}^{\circ}$ 5, pp 1295-1312.

[35] Wyns R., Baltassat J-M., Lachassagne P., Legchenko A., Vairon J. and Mathieu F. (2004). Application of SNMR sounding for groundwater reserves mapping in weathered basement rocks (Brittany, France). Bulletin Société Géologique France, Vol. 175, №1, pp. 21-34. 